\title{
Correction to: Feasibility of a combined supervised and home-based whole-body vibration intervention in children after inpatient oncological treatment
}

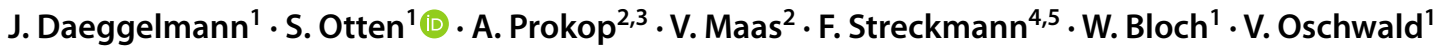

Published online: 20 July 2021

(c) The Author(s) 2021

\section{Correction to: Sport Sciences for Health https://doi.org/10.1007/s11332-021-00770-7}

Unfortunately, the 5th author name has been incorrectly published in the original publication. The complete correct name is given below.

Fiona Streckmann

The original article has been corrected.

Open Access This article is licensed under a Creative Commons Attribution 4.0 International License, which permits use, sharing, adaptation, distribution and reproduction in any medium or format, as long as you give appropriate credit to the original author(s) and the source, provide a link to the Creative Commons licence, and indicate if changes were made. The images or other third party material in this article are included in the article's Creative Commons licence, unless indicated otherwise in a credit line to the material. If material is not included in the article's Creative Commons licence and your intended use is not permitted by statutory regulation or exceeds the permitted use, you will need to obtain permission directly from the copyright holder. To view a copy of this licence, visit http://creativecommons.org/licenses/by/4.0/.

Publisher's Note Springer Nature remains neutral with regard to jurisdictional claims in published maps and institutional affiliations.
The original article can be found online at https://doi.org/10.1007/ s11332-021-00770-7.

S. Otten

s.otten@dshs-koeln.de

1 Department of Molecular and Cellular Sport Medicine, Institute of Cardiology and Sport Medicine, German Sport University Cologne, Am Sportpark Müngersdorf 6, 50933 Cologne, Germany

2 Clinic for Children and Youth Medicine, Pediatric Oncology/Hematology, Municipal Clinics of Cologne, Children's Hospital Amsterdamer Straße, Amsterdamer Straße 59, 50735 Cologne, Germany

3 Clinic for Children and Youth Medicine, Pediatric Oncology/Hematology, Helios Clinics of Schwerin, Wismarsche Straße 393-397, 19049 Schwerin, Germany

4 Department of Sport, Exercise and Health, University of Basel, Birsstr. 320B, 4052 Basel, Switzerland

5 Department of Oncology, University Hospital Basel, Petersgraben 4, 4031 Basel, Switzerland 